ESJ Humanities

\title{
Othering Europe: Ambivalence in Moroccan Discourse Towards Modernity under the Dogmatic Understanding of Islam and the Political Affiliation to the Monarchy
}

\author{
Hamza Salih \\ Mohamed V University, Rabat, Morocco
}

Doi:10.19044/esj.2021.v17n42p1

Submitted: 24 September 2021

Accepted: 02 December 2021

Published: 31 December 2021

\author{
Copyright 2021 Author(s) \\ Under Creative Commons BY-NC-ND \\ 4.0 OPEN ACCESS
}

Cite As:

Salih H. (2021). Othering Europe: Ambivalence in Moroccan Discourse Towards Modernity under the Dogmatic Understanding of Islam and the Political Affiliation to the Monarchy. European Scientific Journal, ESJ, 17 (42), 1. https://doi.org/10.19044/esj.2021.v17n42p1

\begin{abstract}
This paper is a study of the reaction of the Moroccan intellectual elite against/towards European modernity in the nineteenth century. The primary focus is on the Moroccan failure to formulate and develop a positive and reasonable response to European expansionism and menace. This threat may seem military in its core as it was related to colonialism, yet the encounter was essentially cultural and the reaction of the Moroccan elite took its grounds from religious and cultural stands. This is simply because Europe was not only a colonizing Other, but also a cultural opponent with which Morocco had armed conflicts, long-standing rivalries, and even cultural dialogues. This paper develops an argument that the Moroccan intellectual elite exemplified via ambassadorial travel writers, the Makhzen's envoys to Europe, failed to see Europe as a possible model or at least to open some horizons of cultural dialogue and encounter. Due to cultural reasons and historical circumstances, this intellectual elite rejected Europe and modernity. The present paper limits itself to the question of ambivalence shown by Moroccan ambassadorial travel writers in their narratives. It argues that their travel accounts were torn between the writers' religious thinking and political affiliations. It postulates that ambassadorial travel writers showed ambivalence in their connection to the idea of modernity. Their narratives were governed by the dichotomy of admiration of the material progress of Europe and rejection of Europe as a
\end{abstract}


possible cultural model.

Keywords: Moroccan intellectual elite, Ambassadorial travelers, Islam, Monarchy, ambivalence

\section{Introduction}

It is a fact historically proved that the nineteenth century was so critical and decisive for non-Western nations with regards to the questions of modernity and modernization. ${ }^{1}$ The winds of reform and modernization blew from Europe to the rest of the world either through colonization or through other cultural channels and direct contact with other nations. These winds were generally considered as a credible threat to the independence of these nations, and hence this inescapable contact with Europe brought about heated debates among traditional intellectuals concerning the idea of modernity and the necessity of modernization. There was no excluded middle to face European potential menace as there prevailed two principal possible reactions; either to open doors to the new winds of modernity and modernize internal social, political, and economic structures as Japan for instance did, or to strengthen the nation's self-centralization as a means of resistance as the case of Morocco demonstrates. Like all other nations on the southern coast of the Mediterranean, Morocco and its intellectual elite became aware of the development taking place on the northern coast. In fact, for the first time by the second half of the nineteenth century, after the successive defeats of the Battles of Issei (1844) and Tetouan (1860), Moroccan sultans and intellectuals felt the increasing threat of Europe and became aware of its material, civilizational, and military development.

Morocco failed to formulate and generate a satisfactory response to Western expansionism in the nineteenth century. This is because Moroccan

1 Throughout the whole paper, the word modernity designates a distinct cultural and intellectual program that has shaped the Western mind since the European Renaissance, through the Enlightenment, to the Industrial Revolution. Though it has material extensions, modernity should be understood in its pure philosophical sense as a structural system of thought that has epistemologically broken from the pre-capitalist traditional dogmas. On the other hand, the word modernisation is used centrally in sociology more than philosophy. In the context of this thesis, it refers to the transposition and transformation of non-industrial societies at the professional, technical, and administrative levels. Modernisation can also be described as the establishment of institutions which support this transposition. These may include hospitals, schools, universities, and bureaucracies. Sometimes, modernity, the West and Europe can be used interchangeably in this work since from the perspective of nonWestern societies the reaction to Europe as a colonial geographical entity implies reacting to the modern European reforms and liberal spirit as opposed to traditionalism. In this context, Laroui argues that Europe remains an idea and a spirit, and not a geographical location. The present work follows this conception. See Abdullah Laroui, Al- 'Arab wa al-Fikr al-Tarikhi [The Arabs and the Historical Thinking] (Casablanca: Centre Culturel Arabe, 1998) 52. 
reaction to the Western intrusion did not trespass policies and measures sustaining the country's self-centralization. The colonization of Algeria in 1830 and the Moroccan direct encounter with and defeat by the French modern army in 1844 constituted a turning point in Moroccan conception of the Self, the Other, and the world. This conception could no longer ignore the prevalence of a new geopolitical and historical reality where a Christian entity broke the continuity of Dar al-Islam, and hence represented an impending danger to the country. However, "Europe, whether liked or disliked, had imposed itself upon the Moroccans as a permanent element of their daily preoccupation and an essential feature of their conception of the world" (El Mansour 1989, p. 37). In such a novel historical context, the European presence in the region and its threat to Moroccan independence became an inescapable fact which necessitated rethinking the dialectics of the Self and the Other at the social, economic, and cultural levels. There prevailed in the nineteenth century within Moroccan intellectual elite certain negative, inflexible and uncompromising attitudes towards the issue of modernity and modernization. Such attitudes could by no means consider Europe as a paragon that had reached its apotheosis and established its civilization on solid modern grounds, and could by extension serve as an excellent model of reform. Moroccan economic, political, cultural, and intellectual selfcentralization was substantially reflected in the way Moroccan ambassadorial travel writers viewed Europe and modernity.

\section{In the Land of the Christians: Travel as a Sinful Profane Business}

Generally, the number of ambassadorial travel narratives in itself compared to that of pilgrims' travels is significant to our discussion. In the nineteenth century, hundreds of pilgrims' travels were written, while ambassadorial travel accounts did not exceed seven accounts. The low number of this literary genre demonstrates beyond a shadow of a doubt an underlying tendency among Moroccan ambassadors not to report on Europe and modernity. The Moroccan travelers to Europe were hesitant and even unwilling to recount their experiences in the territories of the Christians and cast them into concrete pieces of writing. The Rihla hajiya / hijjaziya flourished in this period because of the widely held belief that the traveler had to share his experiences of piety and sanctity in the holy shrines of Islam, Mecca, and Medina, with fellow believers. He desired above all to route the blessings and knowledge of the 'ulama from all parts of the Islamic world to other devout believers; proselytization was a moral and religious obligation. The pilgrims' travels to the Hijaz remained important for Moroccans to accomplish an enriching, though risky, voyage; "it also provided a lasting personal experience. This is probably one of the reasons for the flourishing of the hijaziya accounts in comparison to other types of rihla accounts," 
according to Abderrahmane El Moudden (1990, p. 73). More than this, this type of travel had an integrative function within Dar al-Islam, unlike the travels to Europe.

El Moudden (1990) adds that the haj and the rihla strengthened the connections of Moroccans with other parts of the Muslim world. He argues:

Through these various aspects, rihla texts testify that the journey to the Hijaz was an important means of integration of Moroccan pilgrims within the wider Muslim community. Moroccan travelers never felt completely foreign towards the inhabitants of the various pilgrimage itineraries. There was no great linguistic handicap for them, at least among the Muslim communities of the southern Mediterranean (p. 74).

By contrast, the journey to the West was viewed with mistrust as an unforgivable volte-face that required religious and theological justifications. Despite being a mandatory mission to carry out the orders of His Highness (the Sultan) which was in itself a religious obligation, the incentives of the travel to the West should be clarified to the audience of the travel accounts in order not to be accused of apostasy and inversion. Once the traveler set off for a journey to the West, the worlds of the travel accounts' producers with the expectations of their audience resulted in many religious and cultural problems. There was a view widely held that travel could by no means cross the frontiers of Dar al-Islam as "only Muslim territories can be visited" as a hadith goes. In Islamic theology, Muslims do not have the legal and religious right to visit the land of unbelievers unless they are in conquest or jihad.

The ambassadorial travels in the nineteenth century were a direct channel whereby Moroccan ambassadors/travelers got into close touch and first-hand experience with European modernity. Such seemingly shocking modernity brought about an amalgam of grudging admiration and the religious necessity of rejection. The dogmatic and conservative religious background governing the tradition of travel writing necessitated sanction to write about the Christians. The travel writer would ultimately be discredited if he wrote about or praised the unbelievers. In his Ithafo al-akhyar bi Ghara'ibi alAkhbar, for instance, Idriss al-J'aidi (2004) warns against "what is usually said by the common men who keep roving in the lands of the Christians and praise their conditions and laws. We pray that God protect us from believing in such a way and beg Him for virtuousness" (p. 104). In the last paragraph of his travel account, Mohammed As-Saffar (1992) similarly washes his hands-on on what he previously wrote. He concludes his narrative as follows:

May God forgive for what my hands have committed, for the repulsive abominations my eyes have witnessed; and for the abhorrent blasphemies and confused mutterings of the misguided that my ears have heard. I ask Him to lead me back to the path of the righteous, even 
though I am not their equal in good works, and to bring my days to a favorable conclusion (p. 221).

Ben Driss Lamraoui (1986) implicitly deprecates and turns his back on what he wrote in his travel account. He begs for the forgiveness of God and of commentators who might misinterpret the rationale behind his act of writing about the Christians. The closing part of his narrative reads as follows:

May critics and commentators condone what my pen erred and pardon the inquisitiveness of my words. And if they identify any defect, shall they enfold it. May they pronounce favorable judgment on me as I have never digressed from the right path; nor shall I. If I haphazardly went into details concerning their [the Christians] life, or I anywise praised some of their acts, it is because I originally intended to bring into attention what conforms to the Sharia and what is accepted by reason and spirit... May God pardon me and wash away my sins (pp. 125126).

The act of writing about unbelievers is sinful as these instances show that the Moroccan ambassadorial travel writers disclaimed responsibility for what they put into words, and by extension, they disavowed every aspect of European modernity that they described or even praised. They can by no means escape conceptualizing the world detached from the dichotomy of the Muslim Self and the Christian/unbeliever Other. The presence of certain religious zealotry molded structurally within the system of the Islamic learning in general and the rihla literary tradition, in particular, obliged the authors of these narratives to repudiate writing about the infidels and their manners. El Mansour (1989) convincingly argues that the nineteenth-century ambassadorial travel accounts "often begin and end-up with presenting apologies to the reader for daring to devote a literary genre traditionally associated with devout purposes to the description of worldly phenomena which, furthermore, were part of the infidel's world." He adds that "the author had to beg his reader's indulgence lest they accuse him of depreciating his Islamic identity and praising the infidel's achievements" (p. 38). The act of writing the travel accounts itself did not stem from the travelers' conviction, but the request of the Sultan. As-Saffar (1992), for instance, clearly asserts that the writing of Rihla ila Faransa was a mandatory response to the request of His Highness, the Sultan. His conclusion of the rihla reads as follows:

That is all that is possible for this poor insignificant self to do, given his muddled brain and the pressures of other work. Were it not for the sake of helping him whose request is hereby answered-for obedience to him is an obligation-I would not have completed it. Nor could I have done it had my knowledge and learning been deficient in 
following the right path. But the blessing of obedience refilled the quiver of my thought and saved me from embarrassment (p. 220).

Unlike the rihla hijaziya which stemmed from a personal motivation to recount the traveler's experience in the holy lands and share them proudly with the devout believers, the recording of ambassadorial travels to the West was necessarily executed only in compliance with the request of the Sultan.

To strengthen their arguments for both contributing to and writing about the embassy, the Moroccan ambassadorial travel writers endeavor to bring into light the rationale behind the travel. However implicit the real reasons might be, they struggled to find justifications for undertaking these journeys to the West and thereby they secure the Sultan's position and present him to the 'public opinion' as a defender of the Sharia with no violation. ${ }^{2}$ AsSaffar (1992), for example, holds that his embassy would bring benefits to his Muslim community and protect His Majesty's people. He states:

[The Sultan] was inspired to send an envoy to the king of the French, so that some benefit might result from it for Muslims and Islam. He decided on it according to sound judgment and good sense, mindful of his duty to watch over the orderly affairs of all our people, both highborn and low. It has always been the concern of the leaders of our community to protect the people of our faith. The Prophet, God bless him and grant him salvation, often sent out the best from among his companions on missions, providing an example followed by the rightly-guided Caliphs and Imams, as we know from the sources (p. 76).

As-Saffar here invites a sort of religious argumentation and gives the instances of the prophet and the Rightly-Imams who often sent envoys to the lands of unbelievers to convince the people of the legitimacy of such a seemingly unusual journey. Because the Prophet, as the highest religious authority in Islam, would send ambassadors and messengers to the lands of unbelievers and Christians, As-Saffar legitimizes the act of the Sultan of sending an embassy to Europe. For As-Saffar, His Majesty would not have sent an envoy to France if there had not been some sort of benefits that would be brought to both Islam and Muslims. He goes so far as to argue that this embassy endeavors to accomplish the primary purpose of demonstrating "the superiority of Muslims and Islam over the worshippers of idols and the proclaimers of fatherhood and sonhood. As it says in the hadith: 'God have mercy on him who shows strength at the right time" (p. 77).

\footnotetext{
${ }^{2}$ Most ambassadorial travel narratives never revealed the real diplomatic and political reasons behind their embassy. This remained among the secrets of the State which had to be kept in the dark.
} 
Lamraoui (1986) similarly vindicates the undertaking of the embassy from a religious perspective and associates it with what is imposed by the "l'intéret religieux" of the Muslim community. He declares:

When the Sovereign, may God glorify him, realized the aggressive action of the Europeans and their attacks against the coastal sites and their intolerably aggressive acts which shake the unshakable, he rushed to redress the situation and he identified the weakness and provided the needed balm. In accordance with religious interest, his majesty, may God strengthen him, appointed ambassadors to go to the surrounding countries of the Franks (Christians) may God destroy them. He did this in order to further whatever promotes harmony and to eradicate the root of hatred and conflict and to provide the necessary defensive tools in preparation for the unforeseeable till he is adequately prepared (p. 33).

In this quote, Lamraoui defends the Sultan's position that the embassy targets the common good and the general interest of the people. Protecting the coasts and frontiers of the country remained a religious priority and obligation. The nomination of ambassadors to the neighboring Christian nations stemmed from such an obligation that necessitated protecting the interests of the Muslim community by all means, including traveling to the lands of unbelievers. Ahmed Idrissi Alami (2013) argues that Lamraoui "celebrates the Moroccan Monarch stewardship and astuteness as a Muslim leader whose wise and insightful policies contrast with the aggressive assaults of the Christians." "Having reminded the reader of the immediate contentious circumstances that have dictated this diplomatic action," he added, "he then describes the mission entrusted to him by the sultan as relevant to the interest of Islam and the 'general good"' (p. 46).

Mohammed Tahar al-Fassi (1967) imputes the Sultan's embassy to England based on the unerring conception of His Majesty to fight for the wellbeing of his Muslim community. Using a religiously-loaded language, he holds that "The Sultan's 'majestic' point of view, after supplicating God for proper guidance, requires sending ambassadors to the French and the English" (p. 2). Adopting a similar tone as As-Saffar's and Lamraoui's, Al-Fassi's traveling to the lands of Christians remains a psychological and moral challenge and danger. To legitimize both this border crossing and the king's political praxis, he similarly calls some examples of the established Islamic tradition. He deems that,

Our commander of the faithful should be commended for sending this embassy since it gives more security and protection to the Muslims and because it uses pacific ways and pacification is necessary whereas flattery is unlawful. The difference between the two, as Kadi 'Iyad 
said, is that pacification is to use secular and mundane life for the benefit of protecting religion and life, while flattery is the exploitation of religion for worldly gain (p. 2).

The tone of al-Fassi here mixes between the religious necessity of pacification and an embedded feeling and experience of weakness. Yet, it remains above all a salvaging mission that endeavors to protect Muslim believers. His Sire commander of believers "did well in this exigency to bring immense benefits to the Muslims ... We beg God to help him destroy despots and defeat unbelievers. (p. 2)"

Moroccan ambassadorial travel writers were cognizant of the paradoxical nature of traveling to the West as it contradicted the prevailing religious thinking. Therefore, their solution, in Susan Miller's words, was "to invoke the formula of masaalih al-umma, 'the welfare of the Islamic people'." Miller (1992) argues that "the journey, according to this argument, merits the approval of the community because it conforms to religious values of protecting the faithful" (p. 54). In this sense, ambassadorial travels acquired some legitimacy of purposes in the same way as rihla hijazya's legitimacy gained prominence for its religious purposes. Talking about As-Saffar who gives the example of The Prophet who "sent the best among his companions" to the territories of unbelievers as he was mindful of the welfare of his community, Miller concludes that "by associating his efforts with the sacred pilgrimage, and by invoking the beneficial results of diplomacy in the past, As-Saffar seeks approval by locating the undertaking within the mainstream of a long tradition" (p 54).

Therefore, Moroccans in the nineteenth century considered the undertaking of the travel to the West and the writing about the Christians and their manners as a profane business. The long apologies afore-cited above ornamenting the beginnings and ends of ambassadorial travel accounts bespeak the inconsistencies of their conception or say their ambivalence of admiration and rejection towards Europe and modernity. Although their accounts are full of vivid depictions of the various fields of the European modern life like the press, the theatre, zoos, printing houses, brigades, libraries, trade, trains, palaces, the telegraph, and the post, the travelers' descriptions show repeatedly a complex of inferiority, astonishment, admiration, and sometimes bewilderment. Al-Makkaoui (2007) points out that "the naïve astonishment of Moroccan ambassadorial travel writers was not only the result of the technical development of Europe, but also because of the simple and ordinary aspects like trees, ships, bridges, roads, theatres, operas, parks, and zoos" ( $p$ 52). So, can Moroccan ambassadorial travel writers trespass the boundaries of mere description and bewilderment into seeking the underlying reasons behind the European power and civilization? 


\section{Othering Europe: Ambassadorial Travellers and Religious Fanatism}

There are indeed many passages from Moroccan ambassadorial travel narratives which powerfully demonstrate a willingness to benefit from European modernity. Yet these writers disseminate visions full of libelous accusation of the impurity of the Christian Other. They view European civilizational development with suspicion and contempt since they could not make a distinction between invading Christian Europe and modern capitalist Europe. In this regard, El Mansour (1989) contends that "the Moroccan reaction to the European civilization in the nineteenth century seemed to be most conservative," compared to the conceptions of other visitors from other parts of the Arab world. "Moroccan envoys," he added, "admired the European technological inventions, but such an attitude did not reflect a deep conviction on their part for the merits of Western civilization" (p. 41). The religious fanaticism of Moroccan travelers, following the intellectual structures of their contemporaneous elite, prevented them from distancing themselves from the physical, social, and cultural phenomena they described. Therefore, religious zealotry can be considered as a determining and decisive parameter that governed the production of meaning in these accounts. Our travelers seemed generally equivocal in their judgments, or say schizophrenic in their "double consciousness" of admiration and rejection as they arguably held a contradictory tendency to vindicate both the unenlightened condition of their home and the purity of their faith. For Moroccan travelers to Europe, the spirituality of Islam must, by all means, be the ultimate endeavor of Muslim believers, instead of whatever material and worldly development.

Moroccan ambassadorial travel writers held that the spirituality of Islam was a thousand times better than the material development of Europe. Although they did acknowledge the superiority of Europeans in order, exactitude, and organization, they depreciated their material progress as the Europeans lack the purity of faith. For instance, As-Saffar (1992) begins his travel account with the postulation that European material development is but a temporary pleasure of mortality. He opines that "to some, He gave a good life in this world, and for others He reserved the pleasures to the thereafter, raising the lowly on high in reward for their good deeds" (p. 74). He calls religious arguments and cites from the Koran: "He will not be tested about what He does; rather, it is they who will be tested" (Holy Coran, 21:23). It is as if he were saying to his audience that what would follow in the travel narrative is of no value since all the development taking place in Europe represents the "belongings of this mortal world" or what Muslims call "mata'e al-donia." After describing the Palais de Versailles in Paris, As-Saffar apologetically confesses that it is a palace of a king who knows no limit or constraint. Yet it is only full of belongings that give pleasure in this life. 
Quoting some verses from the Koran, he advises his readers: "And do not extend your eyes toward that by which We have given enjoyment to [some] categories of them, [its being but] the splendor of worldly life by which We test them. And the provision of your Lord is better and more enduring" (Holy Coran, 20:131).

For As-Saffar and other Moroccan intellectuals of his age, the material strength of Europeans and their religious fidelity was never instantaneously conceivable. That is, they could by no means conceive of development and prosperity without reference to what they called the "true religion." As-Saffar, for instance, makes startling contrast between freedom, righteous conduct, exactitude, justice, and strength of Europeans on the one hand, and the purity of their faith on the other hand. To quote him:

If you could see their conduct and their laws [at work], you would be profoundly impressed by them, despite their infidelity (Kufruhum) and the extinction of the light of religion from their hearts. [As it is said:] "Seeing is believing." May God return to Islam its strength and renew His support for [our] faith with the help of the Prophet, God bless him and grant him salvation (p. 194).

As-Saffar's thinking is vigorously challenged by the shattered remnants of the theological understanding of his inner self as a Moroccan Muslim observer and reporter. He indeed admired some aspects of the European lifestyle and their ongoing progress. As shown above, nevertheless, he solemnly shows some skepticism with regards to the pragmatic reasons behind such progress and the utility of modernity and modernization when the faith is "impure and corrupt." Modernity and modernization were by extension valueless to As-Saffar and his generation of intellectuals in nineteenth-century Morocco. In the extended quote afore-cited, he truly appreciates the building of the Palace of Versailles; simultaneously he advises his fellows not to extend their eyes to what God gave the unbelievers and let them enjoy the flower of the present life. It is paradoxical here that As-Saffar cannot delve into the very fact that European secularism has faith in science, hard work, and reason.

Moroccan travelers in the nineteenth century agreed that Europe had attained economic and civilizational perfection; however, such perfection was a mere sign of collapse and disintegration since it prefigured the seeds of its own destruction because of the absence of religious faith. In this regard, Lamraoui (1986) contends that European modernity, modernization, and material prosperity demonstrate beyond doubt that:

This is conclusive evidence that shows that their [Europeans] affairs have reached the end. Their affairs went beyond what the conventions described and they will soon decline and vanish. It is generally acknowledged that once something reaches its end, it starts to regress 
and that once it reaches the limits of its ascension, it begins to surrender. They boast of their power and they forget about the peril of Thamud, Ad, and the City of a One Thousand Pillars and they did not know that Allah's might dominates them and that nobody can obstruct His orders (p. 86).

Lamraoui holds that civilizational progression without religious fidelity subsequently leads to regression. He reminds Europeans and by extension his readers, following the Khaldounian framework of civilization, that whoever has attained utter perfection and has trespassed the limits of human minds need not forget that they are subject to God's will. In this sense, he seriously questions the utilitarian end and the pragmatic effects of civilizational progress, and hence he centralizes the divine will and abnegates the centrality of human contribution to the formation of history. Lamraoui's intercultural dialogue with European modernity remains ambivalent and governed by the dichotomous distinction between the divine and the profane. He oscillates between acknowledging the perfection of European systems and his ideologically, religiously, and historically dictated desire to repudiate Western modernity.

Like As- Saffar and the intellectual elite in the nineteenth century, Lamraoui (1986) disdains the material development of Western civilization. After he attended a theatrical performance in The Royal Palace, he confesses that Western culture and lifestyle remain within the boundaries of "this dummy mortal world of darkness." As a Muslim observer, the present life can by no means be compared to the otherworldly concerns which must be the ultimate objective of people. On this, he remarks:

It has taken us ages to describe this horror [aspects of modern life in France] even if we have remained silent about so many things. The adornments of the worldly life they are given go beyond words; if set to paper to describe the details of the city and what it holds of beauty, the pen would not reach a limit and we would never be able to end its tedious length and the appraisal of a misleading worldly life. All that is but the ornaments of the present life, its tardiness, its fata morgana, and its triviality. Nonetheless, in being informed about these things and perfectly knowing them, one knows the size of the bounty Allah has bestowed on al-muminin [the believers] by ridding them of the temptation of its seductive beauty and of being conceited by its mortal presence which veers away from the remembrance of Allah's wrath on them. Of such people who are similarly sentenced we have seen examples and their minds resemble ours. Because of His goodness and generosity, He has saved us and made disbelief and wickedness hateful 
to us and hardened us manifestly and latently against their habits (pp. 92-3).

Accordingly, one's raison d'etre in this world is to follow the true religion and neglect whatever concerns this worldly life. By extension, if one believes in the true religion, one is fortunately bestowed the blessing of God, and so there might be no need for modernization and progress which remain but the flower of the present life of mortality. Using such logic, Moroccan ambassadorial travel writers drew illogical dichotomies which did not strike a balance between the two counterparts, and hence they comparatively brought Islam and Europe to the same scrutinizing grounds and faultily see them as contradictory and inconsistent.

Mohamed Tahar Al-Fassi does not similarly trespass the horizons of the prevailing discourse among the Moroccan elite in the nineteenth century. $\mathrm{He}$ seems to be the most conservative among Moroccan ambassadorial travelers as he generates a conservative political stand and typifies a preponderant anti-Western trend of thought. Al-Fassi's travel narrative remains a credible testimony to Moroccan shock of modernity and ambivalence with regards to their relationship to the modern. Like as-Saffar and Lamraoui, al-Fassi (1967) makes a dichotomous distinction between being an unbeliever and having a good sense of morality and conduct. He wonders why "the captain of the ship, despite being an infidel, was so nice to us and he was of great morals, conduct, help, and sense of humor; we wished he had been a Muslim (p. 5). In his logic, although he is infidel, the captain surprises the Moroccan embassy with his kindness, his good manners, and his politeness. Al-Fassi uses religious belief as the sole means of judgment to see the Other and the world generally. In his travel narrative, Al-Fassi, like Lamraoui, tends to interpret European modernizing progress in the light of some fallacious religious arguments which represent Moroccan society and culture as super-incumbent to that of its European counterpart. Put simply, using religious argumentation, he resorts to the rhetoric of vindicating the backward state of affairs in-home and arguing for the claim that he possesses the true religion of salvation. Like other ambassadorial travelers in the nineteenth century, Al-Fassi sees the material development of Western civilization as nonsensical compared to the salvation that the Islamic religion might ultimately guarantee. For him, it is paradoxical that Europeans have reached such an outstanding advancement and ongoing modernization without necessarily following the right path of God. He echoes Lamraoui's standpoint and points out that,

Glory be to God who facilitated all sorts of things for them, although they pursue their own lusts, to show His power in creating contrarieties and opposites; and so that the disobedient realizes that $\mathrm{He}$ has no end 
in closeness or remoteness. If a person pensively and meditatively looks at these things about its Creator and Originator; and he reflected and learned; and he contemplated and recollected; he would figure out that it is nobody other than God who has none comparable to Him (p. $11)$.

Following Al-Fassi's argumentation, it is so strange a doctrine that God gave all these luxuries of the present life to Europeans irrespective of their disbelief. If $\mathrm{He}$ did, Al-Fassi extends the argument, it was principally because He intended to teach the unbelievers that they were interested neither in God nor in the otherworldly. Their material development can be considered as counterfactual evidence which would be used against them in what he calls "the after." Al-Fassi cannot see modernity and modernization as purely human achievements in utterly human history. Contrariwise, he opines that this seemingly unusual European progress is the culmination of God's will and a source of contemplation that conclusively leads one "to believe that there is no God but Allah."

Likewise, Al-Fassi (1967) could not free himself from the religiously dogmatic structures of thought which prevented him from understanding the world detached from the centrality of God's absolute will and the triviality of human endeavors in the formation of history. ${ }^{3} \mathrm{He}$ faithfully echoes the Sunni interpretation of the world in terms of what might be termed "God's determinism." Such an interpretation affected his conception of European modernity in his travel narrative. In more connotative words, Al-Fassi's formulations of Western culture were governed by the oppositional paradigm of the Muslim Self as holder of absolute truth and the "infidel Other" as a stray being in the luxuries of the present material world. He makes it unambiguous when he calls a hadith of the Prophet to argue for the meaningless of the present life and the incalculable value of the afterlife. He describes: "We also found innumerable luxurious utensils, golden and silver chandeliers, chairs furnished with silk and others with gold inlay" (p. 13). He regretfully concludes that "all this is a confirmation of the prophet's saying, peace be upon him, 'This world is the prison of the believer and the paradise of the nonbeliever." (p. 13). To read the silence of such a postulation, there would be no utilitarian end for working on the process of modernization and benefitting from European modernity since Muslims ought to be much concerned with the ever-lasting paradise instead of bothering themselves with the luxuries of

\footnotetext{
${ }^{3}$ In his The concept of Reason, Laroui talks about this problem and attributes the handicap of the "Arab reason" to the so-called "the effective reason" (al 'aql al fa 'al), which means that nothing can happen without the will of Allah and which abnegates whatever human endeavour in the formation of culture, society and history. See Abdullah Laroui, (2007), Mafhoum al'Aql [The Concept of Reason] (Casablanca, Centre Culturel Arabe).
} 
this "mortal prison." It is as if he intended to strengthen Moroccan selfcentralization as a means of resistance against the invading Other and against the urgent necessity of modernizing internal structures to face the fate of Algeria in 1830.

In Moroccan ambassadorial travels, there is a striking presence of dichotomies like otherworldly immortal life (dar al-akhira) / worldly present life (dar al-donia); stable origin of immortality and prosperity / childish toy of imitation and temporality; the sacred and divine / the impure and corrupt; enlightened reason / dark reason; transcendental and absolute truth / immanent technology and rational thinking (Heimer 2005, p. 154). Therefore, they seem to be influenced by their religious thinking in formulating conceptions about Europe, modernity, and modernization. The religious conception of the world was not the only hindrance to positive reception and perception of Europe and modernity, there prevailed also an apparent influence of their political affiliations to the Makhzen on their narratives. ${ }^{4}$ The question in this context is: To what extent do they transcend the political constraints imposed by their political missions in official embassies with loyal affiliations to the Makhzen? In other words, could ambassadorial travel writers extricate themselves from writing their accounts from the standpoint of Makhzani discourse?

\section{Othering Europe: Ambassadorial Travellers and Political Affiliations}

Moroccan ambassadorial travelers in the nineteenth century were caught by a dilemma over the political and institutional development of Europe. Indeed, the degree of their engagement with the political question and liberal principles of European civilization differs from one traveler to another. This engagement ranges from a partial acceptance of liberal ideals exemplified by Mohamed As-Saffar to a total rejection of European political choices epitomized by Tahar al-Fassi. Yet, there prevailed a general tendency within the Moroccan travelers to write from the standpoint of the Makhzen and to take into account their official political mission and their special audience (the Sultan) whose political system lagged behind compared to the constitutional progress of Europe. In other words, since all ambassadorial travel writers traveled on official missions with specific purposes to fulfill, they could not escape being influenced by their political affiliations to the Sultan and the

\footnotetext{
4 The word makhzen literally means "warehouse" in Moroccan Arabic (from khazana "to store up"), where the Sultan's civil servants used to receive their wages; but this word later took new political meaning and became synonymous with the dominant political and military elite. It is likely a metonymy related to taxes, which the makhzen used to collect; the term may also refer to the state. In fact, the Makhzen is a very ancient notion in Morocco. It roughly coincides with the notion of the feudal state which predated the French occupation to Morocco.
} 
monarchy and by the dominating structures of thought in the nineteenth century. Since their belief that monarchy derives its legitimacy from "the divine", dominates their system of thought, Moroccan ambassadorial writers could not ventilate their views on the ongoing political, institutional, and constitutional transformations that took place in Europe in the nineteenth century. Reading the situation backward, praising deliberations of French or British parliaments and their communicative legislations implies indirectly the backwardness of Moroccan monarchical political system and otherworldly legitimacy in the age of pure reason that Moroccan ambassadorial travel writers experienced during their visits to Europe.

From the very beginning of their travel narratives, the Moroccan travelers start with a long, usually poetic, appraising acclaim to the Sultan. This might be attributed to the fact that they use their prefaces to laud the Moroccan Sultan and ensure him of their position as loyal makhzani reporter and observer of the progress going on in Europe. In the travel literature writing tradition, generally, the traveler begins with a khotba praising God and His Prophet and thanking Him for the chance he is given to set off for a voyage or sojourn. ${ }^{5}$ However, in ambassadorial travels praise to the Sultan imposed itself as an overriding part of the "holy trinity," God, the Prophet, and the Sultan, that should be mentioned in the khotba ornamenting the beginning of the travel narrative. As-Saffar, for instance, begins his travel narrative with an eloquently poetic introduction praising the sultan, showing obedience to him, and guaranteeing his benevolence; it reads as follows:

The virtue of all this is attributable to the favor that Allah has delighted the heart of our lord, the beacon of our religion and life, the great, the glorified, the renowned, the revered Sultan, the pride of the people, and the defender of the faith, the beauty of Islam and the master of everyone. His distinctive characteristics derive undoubtedly from the nobility of his origin and lineage, his high estimation and nomination, the nonchalance of his morals, and descent from the master of all the Arabs and non-Arabs. May Allah grant him a perpetual triumph and support. May Allah smooth out the path ahead of him so that all the free subjects be enslaved by his slaves. May Allah bestow on him all the blessings in all its good fortunes and proportions and succumb all the wicked to his sword. May Allah expand his prosperity upon the face of the earth and grant him a rule that no one would ever aspire for. May Allah give the Caliphate exclusively to his successors, bestow him long life and delight his people in him (p. 92). ${ }^{6}$

\footnotetext{
${ }^{5}$ This is particularly true for the hijaziya travel narratives where travellers thank God for the spiritual experience they gain from their visits to Mecca and Medina or from their ziyara-s to holy shrines of some Sufi mystics.

${ }^{6}$ The translation of this quote is mine. It is not taken from Miller's Disorienting.
} 
In this extended passage, as-Saffar originally intends to convince the Sultan of his unwavering loyalty to him and to offer a guarantee that his sojourn to the "lands of unbelievers" would have no undesired consequences. By extension, As-Saffar's actions, words, or ideological interests would not transgress the rules established by the Makhzen. It is legitimate to say in this context that his avowal or silence on many political issues in itself can never be innocent. The disseminated visions and attitudes remain shaped to a great extent by the existence of a special audience, the Sultan, with the necessity of religious protocol and ideological correctness. As-Saffar's comments on justice, legislations, equity, and deliberations disclose themselves implicitly between the lines of his narrative, and never can they trespass the limits of voicing his worries about political affairs explicitly.

Idrissi Alami's (2013) reading of the political implications of AsSaffar's travel narrative is significant in this regard. He argues that As-Saffar's position as faqih and affiliate of the official mission put constraints on the freedom of his critique. The inherent comparative thrust of his response to the facets of French political life reveals the radical entanglement between descriptive representation and social and political critique (p. 55). Put simply, unlike Eastern travelers like Tahtawi and Tounssi, As-Saffar tends to carefully choose the subject of his descriptions of European constitutional and institutional development since the violation of this principle directly alludes to certain political discredit on the Moroccan makhzani monarchical system. He can never openly dispute monarchical authority knowing that he has witnessed the positive political transformations of Europe. Many times, AsSaffar alludes to the prevalence of law, equality of all citizens, the right of criticizing the monarch and the government in the press, along with the transparency of legislation and political practices. Yet, although his reflections on the institutional structures of the French and the public service function as a "political subtext" in Idrissi Alami's words, As-Saffar can never clearly sound like an advocate of the French political model (2013, p. 55). The prevalence of secular law and its paramountcy to European progress as opposed to the religiously established Sharia as a legal system in the home strengthened the ambivalence of As-Saffar and other travelers. In this sense, Moroccan travelers do acknowledge the supremacy of law as a basis for social justice and economic prosperity; nevertheless, they could not bring it comparatively to the same grounds with the Islamic Sharia whose principles were indubitable. Following Jacques Derrida, in all deconstructive reading there must exist a necessity with which what the writer does see/say is systematically related to what he does not see/say (1981, p. 158). Therefore, to undo As-Saffar's text deconstructively, it signifies that such direct comparisons shroud As-Saffar's observations about political subjects within the realm of the unsaid. Having the circumstances of decadence and regression 
at home in mind, As-Saffar might bring certain theological and religious challenges to the legitimacy of the Sultan's rule whose otherworldly legitimacy did not sufficiently bring about certain practical and concrete transformations at the political, economic, and social levels.

Similarly, Mohamed Taher al-Fassi (1967) begins his ambassadorial travel narrative with deep expressions of loyalty and subservience to his Sire, the "defender of religion and the Islamic Umma." The dominant ideology disseminated in this preface strongly implicates an indispensable necessity to meet the horizons of his implied readers, namely the Sultan, and provide them with a sort of indisputable warrant to keep reproducing the same ideology as an affiliate faqih. To show his unwavering ideological correctness, al-Fassi starts his narrative as follows:

And God blessed the Moroccan realms and Idrissian territories with the rule of the exalted and triumphant Sultan Sidi Mohamed, whom God permitted to defend the religion and the people and to dispel all sorrows on the Islamic Umma. He has brought faith's traces into light after fading away and has made our days happy after sorrow and sadness ... I supplicate God to destroy the wicked unbelievers and protect His majesty and guide him in serving the well-being of his Muslim subjects (p. 1-2).

Such a part of the khotba ornamenting the beginning of al-Fassi's travel account is reminiscent of that of As-Saffar who shells his readers with eloquent expressions of excessive praise and blesses to the Sultan. Al-Fassi shows from the start his unquestioning obedience and political affiliation to the makhzani political system in general and the Sultan in particular. He goes as far as to bombard his European hosts with curses with religiously dogmatic zealotry. Throughout his al-Rihla al-Ibriziya, Al-Fassi keeps silent about the constitutional development of liberal England and never delves into the political foundations of the economic and social prosperity he experienced first-hand. Due to his limited education and simple common sense compared to As-Saffar and Lamraoui, Al-Fassi describes the British State as if it were a Makhzen with no difference except in its tremendous power founded on science, the technique, the exactitude, and the organized army (Heimer 2005, p. 152). Al-Fassi's silence on politics in England can be read as a deliberate choice with ideological dimensions; his selections of technological inventions, arsenals, and army as a subject of description instead are never innocent.

Idriss J'aidi Slaoui (2004) does not establish himself as an exception in this regard. He assures the Sultan from the very beginning of his travel narrative of his ideological alignment with the makhzani system. He similarly begins his travel account by lauding praises to the Sultan. His introduction reads as follows: 
May God, by his grace, make his end favorable and perpetuate his well-being in His pleasing and obedience. The glowing face of our magnificent prince shine in this Moroccan territory; his awesome highest Excellency; the disseminator of justice in the country; who is welcomed with submission and obedience in villages and cities; the one to whom all towns and cities pledged allegiance; his glorious deeds are recognized by the general and the particular and his remarkable achievements overwhelm stars and outnumber clouds in support of religion; the leader of invaders and warriors and the rightful heir of the principality's ranks (pp. 98-9).

In other types of travel writing, including the rihla hijaziya, this part of the initiating khotba was never included, and even in other ambassadorial travel accounts before the nineteenth century, the writers began their travel accounts with praising God and the Prophet and moved on to the main subject of the rihla. ${ }^{7}$ Ambassadorial travel writers in the nineteenth century established this tradition of praising the Sultan and showing loyalty to him as conventional in travel writing.

\section{Conclusion}

As a matter of conclusion, the sojourns of Moroccan ambassadors and their scribes in non-Muslim territories posed a real ideological, theological and political challenge to Moroccan travelers when casting their experiences in Europe into concrete pieces of writing. The latter disseminated a marked reluctance both to travel to Europe and to write about modernity. On the one hand, travel to the lands of Christians was politically and ideologically defended and legitimized by the urgent necessity to protect the Muslim community. On the other hand, the act of writing of their travel narratives on the unbelievers remained lawful as long as it is a response to "whose request is hereby answered," in As-Saffar words. Still, these ambassadorial narratives represented a reliable testimony about the intercultural dialogue between Moroccans and modernity in the nineteenth century. They faithfully mirrored the general tendency governing the Moroccan intellectual elite of the time concerning the idea of modernity and the necessity of modernization. The ambassadorial travelers constituted the backbone of what Heimer calls "Makhzeni writers." He terms them so because they were chosen for these

${ }^{7}$ See for instance in the seventeenth century, see Ahmed Ben Kassem al-Hajari Afouqay, 2004, Rihlat Afouqay al-Andaloussia (1611-1613), ed. Mohamed Razzok (Abou Dhabi: Dar Souidi li Nashr wa al-Tawzi'e). See also Mohamed al-Ghassani's al-Andaloussi, 2002, Rihlat al-Wazir fi Iftikak al-Assir (1690-1691), ed. Noury al-Jarah (Abou Dhabi: Dar Souidi li Nashr wa al-Tawzi'e). And in the seventeenth century see Ben Otman al-Maknassi, 1965, al-Ekssir fi Fakak al-Assir, ed. Mohamed al-Fassi (Fes: Mohamed 5 University). 
embassies since they usually held strong positions within the system of the Makhzen and they seemed to guarantee faithful reproduction of the political, ideological, and religious ethos of the political system at home. Their positions as Makhzeni writers influenced the production of meaning in their textual productions and their conceptions of the intercultural dialogue between the Self and the Other. Knowing the state of decadence at home economically, politically, and socially, Moroccan ambassadorial travel writers never openly and seriously questioned their "religious and monarchical idols." Their embedded critique and implicit strictures fell prey to the constraints of ideological and religious correctness that limited their freedom of avowal as faqih-s and representatives of the official embassy. That is why Moroccan descriptions and inscriptions of Europe remained generally oscillating between the implicit advocacy of Western advances politically and socially and the ideologically, politically, and historically imposed dictation to reject and disavow all aspects of Western civilization.

Moroccan cultural dialogue and encounter with Western modernity exemplified by these Makhzeni writers disclosed within the dichotomous structures of the Muslim Self and the Christian Other. These encounters, in fact, "highlight the tension and asymmetrical structures of power that underpin the texture of cultural dialogue" (Idrissi Alami 2013, p. 48). In the ambassadorial travel narratives examined here, vindications were always given for the regressing state of the Self for the advancement of the European Other. Moroccan travelers interpreted European progress in a sense that they belittled European modernity which they saw as an ultimate manifestation of God's will and simultaneously presented their culture as superior to that of their European counterparts. Instead of directing their attention to genealogically delving into the very foundations underlying European modernity, ambassadorial travelers limited themselves to looking for theological and supernatural justifications for their current state of affairs; and instead of creating a third space for cultural encounters, compromise, and negotiation, they created spaces for rejection with no a possibility of an encounter. Instead of pondering carefully into the secrets behind European modernity, Moroccan travelers bombarded the infidels with libelous curses and accusations of impurity and lustfulness. All of these (im)possibilities were historically and culturally justifiable from a historicist perspective and they decentralized the discourse of these ambassadors to occupy shaky discursive grounds.

The dogmatic religious thinking and the Makhzani political affiliations of the Moroccan ambassadorial travelers prevented the dissemination of a discourse of modernization full of reform proposals. Compared to Eastern travelers, no Moroccan traveler brought forward concrete reform proposals. The advocacy of some of European social and economic tenets always hid 
between the lines of their narratives and never could they call explicitly for the urgent need of modernizing the decaying social, economic, and political structures. As a part of the intellectual elite in the nineteenth century, ambassadorial travelers, with so unstable a discourse, could claim no agency of reform. Such attitudes still prevail nowadays in the Islamic world and echo the conceptions of the Moroccan travelers in the nineteenth century who expressed an extreme theological dismissal of the West and modernity as the latter was conceived of as incompatible with the Islamic teachings. "Westerns are responsible for our backwardness and chaotic conditions and eternal conflicts; what is the utility of Western sciences and modernity after all?" This is the discourse that is still disseminated nowadays in all Arabo-Islamic world as a hopeless and desperate reaction against the West, colonialism, and modernity (Heimer 2005, p. 158; Salih 2021, p. 213). It remains an accurate replica of the unstable dogmatic discourse advocated by our intellectuals in the nineteenth century and before; a discourse centralizing the Self as an entity whose sole purpose is tied to the concerns of the otherworldly with no possibilities of negotiating spaces for cultural encounters with the Other on earthly matters. As the case of ambassadorial travel writers indicates, the political parameter remains additionally overriding in the same way as the religious and theological one. The political affiliations of both traditional and organic intellectuals today prevent them from leading their nations to safe shores. As an effective state ideological apparatus, they faithfully reproduce underdevelopment and authoritarianism. They can by any means distance themselves from the centers of political influence. Whatever the case, the image drawn for the West in the present is but an extension of that drawn for it in the imaginary of the Moroccan travelers as traditional intellectuals in the past.

\section{References:}

1. Afouqay, Ahmed Ben Kassem al-Hajari. 2004. Rihlat Afouqay alAndaloussia (1611-1613) [The Andalusian Travel of Afouqay (16111613)]. Ed. Mohamed Razzok. Abou Dhabi: Dar Souidi li Nashr wa al-Tawzi'e.

2. Al-Fassi, Mohammed Taher. 1967. Al-Rihla al-Ibrizia ila Diar alInglizia [The Golden Travel to the Land of England]. Ed. Mohammed al-Fassi. Fes, Mohamed V University Press.

3. Al-Ghassani, Mohammed. 2002. Rihlat al-Wazir fi Iftikak al-Assir [The Travel of the Vizir in Releasing the Captives]. Ed. Nouri al-Jarah. Abou Dhabi: Dar As-Souidi.

4. Al-Makkaoui, Ahmed. 2007. Al-Rahalona al-Maghariba wa Owaspa [Moroccan Travellers and Europe]. Rabat: Jodour li Nashr. 
5. Al-Meknassi, Mohammed ben Ottman. 1965. Al-Ikssir fi Fakaki alAssir [The Elixir of Releasing the Captive]. Ed. Mohammed al-Fassi. Fes: University Mohamed V.

6. Al-Tahtawi, Rifa'a Rafi'. 2011. An Imam in Paris: Account of a Stay in France by an Egyptian Cleric (1826-1831). Ed \& Trans. Daniel L. Newman. London: Saqi Books.

7. Al-Tunissi Khayr al-Din. 1967. The Surest Path: The Political treatise of a Nineteenth-century Muslim Statesman. Trans. L. C. Brown. Massachusetts: Cambridge University Press.

8. Derrida, Jacques. 1981. Dissemination. Trans. Barbara Johnson. London: The University of Chicago Press.

9. Eickelman Dale \& Piscatori James, eds. 1990. Muslim travelers: Pilgrimage, Migration, and the Religious Imagination. Los Angeles: University of California Press.

10. El Mansour, Mohamed. 1989. Moroccan Perceptions of European Civilisation in the Nineteenth Century. Morocco and Europe. Ed. George Joffé. London: Centre of Near and Middle Eastern Studies.

11. El Moudden, Abderrahmane. 1990. The Ambivalence of Rihla: Community Integration and Self-Definition in Moroccan Travel Accounts. Muslim Travellers. Ed. Dale Eickelman \& James Piscatori. California: University of California Press.

12. Heimer, Abdessalam. 2001. Al-Nokhba al-Maghribiya wa Ishkaliyat al-Tahdith [Moroccan Intellectual Elite and the Problematic of Modernisation]. Casablanca: al-Moltaqa.

13. ---. 2005. Al-Maghreb: al-Islamo wa al-Hadatha [Morocco: Islam and Modernity]. Casablanca: al-Najah al-Jadida Press.

14. Holy Koran. 2009. Trans. Muhammad Ghali. Dar Ibn Hazm: Cairo.

15. Idrissi, Ahmed Alami. 2013. Mutual Othering: Islam, Modernity and the Politics of Cross-cultural Encounters in Pre-Colonial Morocco and European Travel Writing. New York: State University of New York Press.

16. J'aidi, Idriss al-Slaoui. 2004. Ithafo al-Akhyar bi Rara'ibi al-Akhbar [Enriching the Dearest with the Strangest Reports]. Ed. Izarab Ma'eninou. Abou Dhabi: Dar As-Souidi.

17. Lamroui, Idriss ben Driss. 1986. Tohfat al-Malik al-'Aziz fi Mamlakati Bariz [The treasure of the Dear king In the Kingdom of Paris]. Ed. Zaki Mubarak. Tanger: E. T. E. I Nord.

18. Laroui, Abdullah. 1998. Al- 'Arab wa al-Fikr al-Tarikhi [The Arabs and the Historical Thinking]. Casablanca: Centre Culturel Arabe.

19. ----. 2007. Mafhoum al-'Aql [The Concept of Reason]. Casablanca: Centre Culturel Arabe. 
20. ----. 2009. Les Origines sociales et culturelles du nationalisme marocain. Casablanca: Centre Culturel Arabe.

21. Miller, Susan, trans \& ed. 1992. Disorienting Encounters: Travels of a Moroccan Scholar in France in 1845-1846: The Voyage of Mohammed As-Saffar. California: California University Press.

22. Salih, H. (2021). Allal Al-Fassi's Utopia: Liberalism and Democracy within the Revivalist System of Thought. International Journal of Language and Literary Studies, 3(3), 202-215. 